\title{
Outcome of pterygium surgery: analysis over 14 years
}

${ }^{1}$ Cornea and Anterior Segment Service, LV Prasad Eye Institute, Hyderabad, India

${ }^{2}$ Department of Biostatistics, LV Prasad Eye Institute, Hyderabad, India

Correspondence:

M Fernandes,

LV Prasad Eye Institute,

LV Prasad Maarg,

Banjara Hills,

Hyderabad 500 034, India Tel: + 914023548267 .

Fax: + 914023548271 .

E-mail: fernandes@|vpei.org

Received: 9 February 2004 Accepted in revised form: 2 September 2004

Published online:

29 October 2004

Financial or proprietary interest: None.

\begin{abstract}
Aim To report the outcome of pterygium surgery performed at a tertiary eye care centre in South India.

Methods Retrospective analysis of medical records of 920 patients ( 989 eyes) with primary and recurrent pterygia operated between January 1988 and December 2001. The demographic variables, surgical technique (bare sclera, primary closure, amniotic membrane transplantation (AMT), conjunctival autograft (CAG), conjunctivallimbal autograft (CLAG), or surgical adjuvants), recurrences and postoperative complications were analysed.

Results A total of 496 (53.9\%) were male and 69 (7.5\%) had bilateral pterygia. Bare sclera technique was performed in $267(27.0 \%)$ eyes, primary conjunctival closure in $32(3.2 \%)$, AMG in $123(12.4 \%)$, CAG in $429(43.4 \%)$, and CLAG in 70 (7.1\%). Adjuvant mitomycin C was used in $44(4.4 \%)$ cases. The mean duration of follow-up was $8.9 \pm 17.0$ and $5.9 \pm 8.8$ months for unilateral primary and recurrent pterygia, respectively. The overall recurrence rate was $178(\mathbf{1 8 . 0 \% )}$. Following primary and recurrent unilateral pterygium excision respectively, recurrences were noted in $46(19.4 \%)$ and $1(33.3 \%)$ eyes after bare sclera technique, five $(\mathbf{1 6 . 7 \% )}$ ) and 0 after primary closure, $28(26.7 \%)$ and 0 with AMG, $42(12.2 \%)$ and five $(31.3 \%)$ with CAG, and nine $(\mathbf{1 7 . 3 \%})$ and two $(40 \%)$ with CLAG. Recurrences were significantly more in males with primary $(23.3$ vs $10.7 \%, P<0.0001)$ and recurrent (26.7 vs $0 \%, P=0.034)$ pterygia, and in those below 40 years (25.2 vs $14.8 \%$, $P=0.003$ ).

Conclusion CAG appears to be an effective modality for primary and recurrent pterygia. Males and patients below 40 years face greater risk of recurrence. Bare sclera technique has an unacceptably high recurrence. Prospective
\end{abstract}

M Fernandes', VS Sangwan', AK Bansal', N Gangopadhyay', MS Sridhar', P Garg', MK Aasuri', R Nutheti ${ }^{2}$ and GN Rao'

studies comparing CAG, CLAG, and AMG for primary and recurrent pterygia are needed. Eye (2005) 19, 1182-1190. doi:10.1038/sj.eye.6701728; published online 29 October 2004

Keywords: pterygium surgery; conjunctival autograft; conjunctival-limbal autograft; amniotic membrane transplant; bare sclera excision

\section{Introduction}

A pterygium is a wing-shaped growth of fibrovascular conjunctiva onto the cornea. Its incidence varies across geographical locations. Several hypotheses have been ascribed to its aetiology. ${ }^{1}$ Currently, it is believed that the pterygium is a growth disorder characterised by conjunctivalisation of the cornea due to localised ultraviolet induced damage to the limbal stem cells. ${ }^{2}$ Aggressive pterygial fibroblasts are also responsible for corneal invasiveness. ${ }^{3}$ The indications for surgery include reduced vision due to encroachment of the visual axis and irregular astigmatism, ${ }^{4}$ chronic irritation and recurrent inflammation, restriction of ocular motility, and cosmesis. Numerous surgical techniques including bare sclera excision with or without the use of adjuncts like beta irradiation, thiotepa eye drops, intra- or postoperative mitomycin C (MMC) or antineoplastic agents, amniotic membrane transplantation, conjunctival autograft (CAG) with or without limbal stem cells have been described. ${ }^{5}$ Despite these innovative procedures, recurrence continues to be a complication. Reported rates of recurrence range from $2 \%$ for excision with CAG to $89 \%$ for bare sclera excision. ${ }^{5}$ Differences in study methodology, patient characteristics, nature of pterygium, geographic area, definition of recurrence, duration of follow-up, and loss to follow-up are some of the factors responsible for 
widely varying rates of recurrence. ${ }^{6}$ Since pterygium has a moderate to high prevalence $30^{\circ}$ above and below the equator, ${ }^{1}$ pterygium surgery is fairly common in our country, which is located within the tropics. We decided to determine the outcome of various surgical techniques for pterygium performed at our Institute over a period of 14 years.

\section{Methods}

A retrospective analysis was performed of medical records of all patients with primary and recurrent pterygia who underwent surgery between January 1988 and December 2001. We assessed the demographic variables, previous history of recurrences and prior pterygium surgeries (if data were available). The duration of follow-up, type of surgery performed (bare sclera excision, primary closure, amniotic membrane transplantation (AMT), CAG, conjunctival-limbal autograft (CLAG), or concomitant use of surgical adjuvants), recurrences with respect to the type of surgery performed and postoperative complications were analysed.

\section{Surgical technique}

The analysis of pterygium surgery outcome spanned 14 years during which time, we have witnessed the evolution of several techniques performed by multiple surgeons. Bare sclera excision and primary closure were performed in the early to mid nineties. Subsequently these were replaced by either CAG or CLAG or human amniotic membrane (HAM). The specific surgical techniques followed for each procedure have remained consistent over the years, and are briefly described below. All patients were anaesthetised with a peribulbar block using 2\% lignocaine hydrochloride and $0.001 \%$ adrenaline tartarate.

\section{(a) Pterygium excision}

The pterygium head was taken off the cornea by blunt dissection with a No. 15 Bard-Parker blade or a crescent knife. The pterygium was then resected from the underlying sclera. Fibrous adhesions, if any, between the underlying muscle and the pterygium were carefully dissected before the pterygium was excised. Minimal wet field cautery was applied to maintain hemostasis. The corneal and limbal surfaces were smoothed by scraping with a Bart Parker blade.

\section{(b) Bare sclera}

Following excision of the pterygium, the sclera was left bare.

\section{(c) Primary closure}

The surrounding conjunctiva was undermined and mobilised to cover the bare sclera. The conjunctiva was then sutured with 8-0 vicryl sutures.

\section{(d) Amniotic membrane transplant}

The human amniotic membrane was prepared and preserved according to the technique described by Kim and Tseng. ${ }^{7}$ After excision of the pterygium, the HAM was removed from the nitrocellulose paper and placed over the bare sclera and cornea with the epithelial side up. The stromal side was identified by its stickiness to a surgical sponge. It was secured in place with 10-0 monofilament nylon beyond the edges of the corneal defect and at the limbus, and to the surrounding conjunctiva with 8-0 vicryl sutures. The excess membrane was trimmed. One of the authors (VSS) prefers to cover the donor site with HAM as well.

\section{(e) $C A G$}

After pterygium excision, the eyeball was rotated down and an area of the superior bulbar conjunctiva adjacent to the limbus, measuring $1 \mathrm{~mm}$ greater than the bare sclera, was demarcated. Blunt dissection of the conjunctiva without the Tenon's capsule was carried out. The limbal tissue was not included. The autograft was slid into place over the bare sclera in its correct anatomical orientation, and was secured in position at the limbus by $10-0$ monofilament nylon sutures and peripherally to the surrounding conjunctiva by $8-0$ vicryl sutures.

\section{(f) CAG with AMT}

In some cases, HAM was spread on the corneal epithelial defect, epithelial side up and was secured in place with 10-0 monofilament nylon sutures in the normal cornea at the edge of the defect, avoiding placement of sutures in the visual axis, and at the limbus. The knots were trimmed and buried. The excess amniotic membrane was trimmed. The CAG harvested as described above was transferred to the recipient bed over the HAM and anchored along with the HAM to the surrounding conjunctiva with 8-0 vicryl sutures.

\section{(g) CLAG}

Harvesting of the CLAG was similar to the CAG in all respects except that on reaching the limbus, the tissue was reflected onto the cornea and the dissection was continued $0.5 \mathrm{~mm}$ beyond the limbus. The donor tissue was excised and slid onto the recipient bed ensuring accurate orientation of the limbal edge of the graft with the limbus. 


\section{(h) CLAG with AMT}

The technique for pterygium excision, harvesting of CLAG and securing HAM was as described above.

Postoperatively, all patients were started on topical steroids, tapered over 6 weeks, and topical antibiotics for a week. Patients were followed up after 1 week, 1 month, every 3 months for the first year, and annually thereafter.

We defined progressive pterygium as any pterygium wherein over a period of 3-6 months, there was an increase in the size as observed by the patient or as documented in the medical record. Vascular pterygium was defined as any fleshy vascularised pterygium, which obscured the view of the underlying episcleral vessels.

We defined recurrence as any fibrovascular growth extending across the limbus onto the cornea at the site of surgical excision. The onset of recurrence was recorded as the date on which the recurrence was first noted, irrespective of the duration between that visit and the previous visit.

All the data were analysed separately for primary and recurrent groups using SPSS (SPSS for Windows, version 11.0; SPSS, Chicago, IL, USA) statistical package.

Between-group differences were evaluated for continuous variables using the two-sample $t$-test and for categorical variables using Fisher's exact test $/ \chi^{2}$ test. Cumulative success probability of recurrence was determined for each group using Kaplan-Meier survival analysis. Risk factors for recurrence were identified in a univariate analysis (log-rank test). The factors having $P$ value less than 0.15 were subjected to a forward selection procedure using a multivariate Cox proportional hazards model. A $P$-value of less than 0.05 was considered statistically significant.

\section{Results}

In total, 920 patients (989 eyes) of whom 496 (53.9\%) were male underwent surgery between January 1988 and December 2001. There was a statistically significant difference in the mean age of patients with primary pterygia compared to those with recurrent pterygia (50.7 \pm 13.4 vs $40.6 \pm 14.4$ years, $P<0.0001$, independent sample $t$-test). The characteristics of the pterygia are presented in Table 1. More than two-thirds of the pterygia were progressive and vascular. Figure 1 shows the indications for pterygium surgery, the main indication being visual impairment in more than half the patients.

We analysed patients with unilateral $(n=851)$ and bilateral $(n=69)$ pterygia separately. The demographic and clinical data is presented in Table 2. The mean duration of follow-up was $6.4 \pm 8.8$ and $9.8 \pm 17.8$ months for primary and recurrent pterygia, respectively. Unilateral recurrent pterygium was significantly more
Table 1 Morphological characteristics of unilateral pterygia and other associated features

\begin{tabular}{lcc}
\hline Clinical features & \multicolumn{2}{c}{ Unilateral } \\
\cline { 2 - 3 } & $\begin{array}{c}\text { Primary } \\
\text { pterygia } \mathrm{n}=821\end{array}$ & $\begin{array}{c}\text { Recurrent } \\
\text { pterygia } \mathrm{n}=30\end{array}$ \\
\hline Progressive (\%) & $516(62.9)$ & $24(80)$ \\
Vascular (\%) & $578(70.4)$ & $27(90)$ \\
Atrophic (\%) & $46(5.6)$ & $1(3.3)$ \\
Nasal + temporal (\%) & $11(1.3)$ & $1(3.3)$ \\
Symblepharon (\%) & $21(2.6)$ & $7(23.3)$ \\
Ocular motility & $42(5.1)$ & $3(10)$ \\
restriction (\%) & & \\
\hline
\end{tabular}

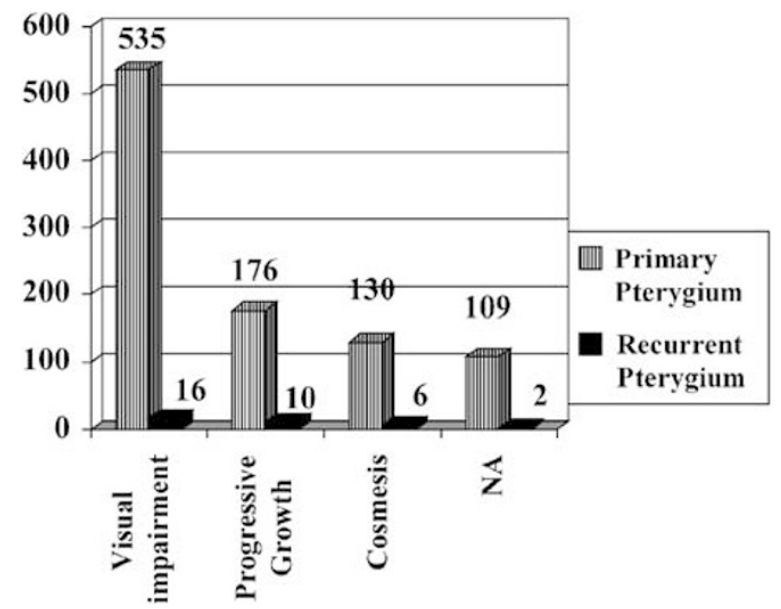

Figure 1 The indications for pterygium surgery in unilateral and bilateral primary and recurrent pterygia. $\mathrm{NA}=$ not available.

Table 2 Demographic and clinical data of patients with unilateral pterygia

\begin{tabular}{lccc}
\hline & \multicolumn{2}{c}{ Unilateral } & P-value \\
\cline { 2 - 3 } & $\begin{array}{c}\text { Primary } \\
\text { pterygia } \mathrm{n}=821\end{array}$ & $\begin{array}{c}\text { Recurrent } \\
\text { pterygia } \mathrm{n}=30\end{array}$ & \\
\hline Age & & & \\
$\quad$ Mean \pm SD & $50.6 \pm 13.5$ & $41.6 \pm 14.4$ & $<0.0001$ \\
$\quad$ Range & $3-94$ & $10-83$ & \\
Gender & & & \\
$\quad$ Male (\%) & $399(48.6)$ & $20(66.7)$ & 0.063 \\
$\begin{array}{l}\text { Female (\%) } \\
\text { Duration of } \\
\text { follow-up (months) }\end{array}$ & $422(51.4)$ & $10(33.3)$ & \\
$\quad$ Mean \pm SD & & & \\
Median & $8.86 \pm 16.97$ & $5.92 \pm 8.78$ & 0.347 \\
Range & 2.49 & 2.93 & \\
\hline
\end{tabular}

$\mathrm{SD}=$ standard deviation.

common in younger individuals (mean age, $41.6 \pm 14.4$ years).

The different surgical procedures and the recurrences with each technique performed for unilateral primary and recurrent pterygia are presented in Table 3 . Three 
Table 3 Different surgical procedures, frequency of first recurrence and median time of onset of first recurrence following these procedures for unilateral primary and recurrent pterygia

\begin{tabular}{|c|c|c|c|c|c|c|c|c|}
\hline \multirow[t]{2}{*}{ Surgical procedure } & \multicolumn{4}{|c|}{ Primary } & \multicolumn{4}{|c|}{ Recurrent } \\
\hline & $\begin{array}{l}\text { Total no. } \\
\text { of eyes (\%) }\end{array}$ & $\begin{array}{c}\text { No. of } \\
\text { recurrences (\%) }\end{array}$ & $95 \% C I$ & $\begin{array}{l}\text { Median time } \\
\text { to recurrence } \\
\text { (months) }\end{array}$ & $\begin{array}{l}\text { Total no. } \\
\text { of eyes (\%) }\end{array}$ & $\begin{array}{c}\text { No. of } \\
\text { recurrences (\%) }\end{array}$ & $95 \% C I$ & $\begin{array}{l}\text { Median time to } \\
\text { recurrence (months) }\end{array}$ \\
\hline Bare sclera & $237(28.7)$ & $46(19.4)$ & $14.4-24.4$ & 2.07 & $3(10)$ & $1(33.3)$ & $0-86.7$ & \\
\hline Primary closure & $30(3.7)$ & $5(16.7)$ & $3.3-30.0$ & 2.72 & $1(3.3)$ & 0 & $0-100$ & \\
\hline AMT & $105(12.8)$ & $28(26.7)$ & $18.2-35.1$ & 4 & $4(13.3)$ & 0 & $0-46.1$ & \\
\hline CAG & 345 (42.1) & $42(12.2)$ & $8.7-15.6$ & 2.64 & $16(53.3)$ & $5(31.3)$ & $8.5-54$ & 1.9 \\
\hline $\mathrm{CAG}+\mathrm{AMT}$ & $20(2.5)$ & $3(15)$ & $0-30.6$ & 3.7 & 0 & 0 & 0 & \\
\hline CLAG & $52(6.3)$ & 9 (17.3) & $7-27.6$ & 5.88 & $5(16.7)$ & $2(40)$ & $0-82.9$ & 1.78 \\
\hline Bare sclera + MMC & $25(3.1)$ & $5(20)$ & $4-35.7$ & 8.92 & 0 & 0 & 0 & \\
\hline Primary closure $+\mathrm{MMC}$ & $5(0.6)$ & $0(0)$ & & & 0 & 0 & 0 & \\
\hline $\mathrm{CAG}+\mathrm{AMT}+\mathrm{MMC}$ & $2(0.2)$ & $0(0)$ & & & 0 & 0 & 0 & \\
\hline $\mathrm{CLAG}+\mathrm{AMT}+\mathrm{MMC}$ & $0(0)$ & & & & $1(3.3)$ & 0 & $0-100$ & \\
\hline Total & $821(100)$ & $138(16.8)$ & & & $30(100)$ & $8(26.7)$ & & \\
\hline
\end{tabular}

No.=number, $\mathrm{CI}=$ confidence intervals, $\mathrm{AMT}=$ amniotic membrane transplantation, $\mathrm{CAG}=$ conjunctival autograft, CLAG $=$ conjunctival limbal autograft, $\mathrm{MMC}=$ mitomycin $\mathrm{C}$.

patients underwent a combination of either CAG or CLAG with AMT and MMC. Of 821 patients with unilateral primary pterygium, recurrences were noted in $138(16.8 \%)$ on an average $6.0 \pm 8.2$ months $(0.66-$ 59.9 months) after surgery. Of 159 patients below the age of 40 years, $40(25.2 \%)$ developed recurrences as compared to $98(14.8 \%)$ of 662 patients older than $40(P=0.003)$. Recurrences were significantly more common in males operated for primary pterygium (93 (23.3\%) of 399 male patients, $P<0.0001$ ) compared to female (45 (10.7\%) of 422 female). In those with recurrent pterygia $(n=30)$, eight $(26.7 \%)$ had recurrences, all of whom were male $(P=0.034)$. The average onset of recurrence was $3.1 \pm 3.1(0.98-10.33)$ months. There was no statistically significant difference in the failure rates between eyes with primary and recurrent pterygia ( $P=0.212$, Fisher's exact test).

Of 69 patients with bilateral pterygium, only one patient had recurrent pterygia in both eyes. In all, $40(58.8 \%)$ patients had surgery in the right eye first and $28(41.2 \%)$ patients had surgery in the left eye first. Eight $(11.6 \%)$ patients underwent bilateral simultaneous surgery. The mean duration between surgery of both eyes in the remaining patients was 11.06 months (range 0.0398.97 months). In $41(60.3 \%)$ patients the same surgery was performed in both eyes. In total, $25(61 \%)$ patients underwent CAG, eight (19.5\%) had bare sclera excision, three $(7.3 \%)$ underwent CLAG, three $(7.3 \%)$ had adjuvant MMC application, and two $(4.9 \%)$ received an AMT. The remaining patients underwent different surgeries in each eye. Table 4 shows the surgical procedures performed in these patients. Recurrences were noted in 32 eyes of 24 patients. In 23 patients with bilateral primary pterygia, the mean onset of recurrence in 14 patients with recurrence in the eye operated on first was $17.2 \pm 21.5$ (1.6-52.9) and $11.6 \pm 17.9$ (1.4-59.1) months in 16 patients with recurrence in the eye operated on second. In six patients, recurrences were seen in both eyes. One patient with bilateral recurrent pterygia developed recurrences in both eyes, at 11.3 months following surgery in the eye operated on first and at 6.3 months in the eye operated on second.

We analysed several risk factors for recurrence including age, gender, laterality, occupation (whether indoors or outdoors), the morphological characteristic of the pterygium, and the type of surgical technique performed. Table 5 shows the results of a univariate and multivariate analysis of these factors for recurrence of pterygium. Since the sample size of those with recurrent pterygium developing another recurrence was small, analysis was not carried out between subsets within this group. A $P$-value $<0.002$ was considered significant after adjusting the level of significance using Bonferroni's correction, for multiple comparisons among the various groups with unilateral primary pterygium undergoing different surgical procedures. A statistically significant difference was noted in the recurrence between bare sclera excision $(P=0.019)$ and amniotic membrane transplantation $(P=0.006)$ compared to pterygium excision with CAG. There was no statistically significant difference among any of the other surgical procedures.

Figure 2 shows the probability of success as a function of time (Kaplan-Meier survival analysis curves) for primary and recurrent pterygia. The mean survival time for primary pterygia was $81.38 \pm 5.44$ months (95\% CI; 70.73-92.04) and 28.93 \pm 5.48 months $(95 \%$ 
CI; 18.19-39.66) for recurrent pterygia. At 1, 3, 6 months, and 1 year, $4.9 \%(8), 44.2 \%$ (72), 68.7\% (112), and $82.2 \%$ (134), respectively, of recurrences $(n=165)$ had occurred. The postoperative complications are shown in Table 6. Graft odema (1.3\%), conjunctival granuloma $(0.8 \%)$, and Tenon's cyst $(0.2 \%)$ were the minor complications noted. Microbial keratitis was seen in three $(0.3 \%)$ eyes 2-

4 weeks postoperatively. Two had undergone pterygium excision and CAG, and one had AMT. All three patients were on topical steroids at the time of presentation and did not have any other predisposing factors. All patients resolved within 3-6 weeks on topical antibiotics. Scleral melt was seen in two $(0.2 \%)$ eyes of patients who had undergone pterygium excision with CAG 2 and 3 weeks earlier. Neither of the patients had evidence of collagen vascular disorders and resolved within 6 weeks on topical and oral steroids.

\section{Discussion}

Pterygium surgery should ideally have a low or no recurrence, minimal complications and be cosmetically acceptable. The evolution of several surgical techniques over the years with recurrence rates varying from 2 to $88 \%{ }^{5}$ indicates that we are yet to find the 'ideal' procedure.

The risk factors for recurrence include geographic location, ${ }^{8}$ age, ${ }^{9}$ and morphology of pterygium. ${ }^{10}$ We have noted that recurrence was significantly higher in males with primary (23.3 vs $10.7 \%, P<0.0001)$ and recurrent pterygia (26.7 vs $0 \%, P=0.034$ ). It was also higher in patients below 40 years of age ( 25.2 vs $14.8 \%, P=0.003$ ) as has been described previously. ${ }^{9,11,12}$ The lipoid degeneration in the peripheral cornea in elderly individuals may be an inhibiting factor to pterygium progression. $^{13}$

The commonest morphological characteristics of the primary pterygia were vascular in $578(70.4 \%)$ and progressive in $516(62.9 \%)$. Among those with recurrent pterygia, vascular pterygia comprised $27(90 \%)$ and progressive pterygia $24(80 \%)$. A significantly higher number of patients with recurrence following surgery for unilateral primary pterygium were noted to have vascular pterygia (18.9 vs $11.9 \%, P=0.026)$. The pterygium morphology has been described as a significant risk factor for its recurrence. ${ }^{10}$ Symblepharon was more common in those with recurrent pterygium and was seen in seven (20.6\%) eyes compared to 21 $(2.6 \%)$ of eyes with primary pterygium.

\section{Bare sclera}

Although this appears to be the quickest and easiest technique, unacceptable recurrence rates ranging from 
Table 5 Risk factors for pterygium recurrence

\begin{tabular}{|c|c|c|c|c|c|c|c|}
\hline & \multirow[t]{2}{*}{$N$} & \multirow[t]{2}{*}{$R(\%)$} & \multirow[t]{2}{*}{$P$-value $e^{\mathrm{a}}$} & \multicolumn{2}{|c|}{ Univariate } & \multicolumn{2}{|c|}{ Multivariate } \\
\hline & & & & $H R$ & $95 \% C I$ & $H R$ & $95 \% C I$ \\
\hline \multicolumn{8}{|l|}{ Age (years) } \\
\hline$<40$ & 159 & $40(25.2)$ & $<0.0001$ & 2.12 & $1.43-3.14$ & 2.13 & $1.41-3.2$ \\
\hline$>40$ & 662 & $98(14.8)$ & & 1 & & & \\
\hline \multicolumn{8}{|l|}{ Gender } \\
\hline Male & 399 & $93(23.3)$ & 0.002 & 1.82 & $1.35-2.66$ & 1.76 & $1.19-2.58$ \\
\hline Female & 422 & $45(10.7)$ & & 1 & & & \\
\hline \multicolumn{8}{|l|}{ Occupation } \\
\hline Indoor & 232 & 31 (13.4) & & 1 & & & \\
\hline Outdoor & 260 & $40(15.4)$ & 0.25 & 1.34 & $0.81-2.22$ & $\mathrm{n} / \mathrm{a}$ & \\
\hline \multicolumn{8}{|l|}{ Progressive } \\
\hline $\mathrm{P}$ & 516 & $84(16.3)$ & & 1 & & & \\
\hline NP & 305 & $54(17.7)$ & 0.935 & 1.01 & $0.71-1.45$ & $\mathrm{n} / \mathrm{a}$ & \\
\hline \multicolumn{8}{|l|}{ Vascular } \\
\hline $\mathrm{V}$ & 578 & 109 (18.9) & 0.026 & 1.63 & $1.06-2.51$ & 1.63 & $1.05-2.53$ \\
\hline $\mathrm{NV}$ & 243 & 29 (11.9) & & 1 & & & \\
\hline \multicolumn{8}{|l|}{ Symblepharon } \\
\hline Present & 21 & $4(19)$ & 0.958 & 1.03 & $0.38-2.78$ & $\mathrm{n} / \mathrm{a}$ & \\
\hline Absent & 800 & $134(16.8)$ & & 1 & & & \\
\hline \multicolumn{8}{|l|}{ Laterality } \\
\hline Unilateral & 821 & $138(16.8)$ & & 1 & & & \\
\hline Bilateral & 66 & $24(36.4)$ & 0.08 & 1.49 & $0.95-2.33$ & $\mathrm{n} / \mathrm{a}$ & \\
\hline \multicolumn{8}{|l|}{ Surgical technique } \\
\hline BS & 237 & $46(19.4)$ & & 1 & & 1 & \\
\hline PC & 30 & 5 (16.7) & 0.103 & 1.51 & $0.92-2.49$ & 1.15 & $0.45-2.93$ \\
\hline AMT & 105 & $28(26.7)$ & 0.185 & 0.74 & $0.48-1.15$ & 1.37 & $0.83-2.27$ \\
\hline CAG & 345 & $42(12.2)$ & 0.975 & 0.99 & $0.39-2.49$ & 0.67 & $0.43-1.05$ \\
\hline $\mathrm{CAG}+\mathrm{AMT}$ & 20 & $3(15)$ & 0.662 & 0.73 & $0.18-3.02$ & 0.54 & $0.13-2.27$ \\
\hline CLAG & 52 & $9(17.3)$ & 0.989 & 0.99 & $0.47-2.13$ & 0.83 & $0.39-1.78$ \\
\hline MMC & 32 & 5 (15.6) & 0.541 & 0.75 & $0.3-1.89$ & 0.64 & $0.25-1.61$ \\
\hline
\end{tabular}

$N=$ no. of patients, $R=$ no. of recurrences (first recurrence), $\mathrm{HR}=$ hazards ratio, $\mathrm{CI}=$ confidence interval, $\mathrm{P}=$ progressive, $\mathrm{NP}=$ nonprogressive, $\mathrm{V}=$ vascular, $\mathrm{NV}=$ nonvascular, $\mathrm{BS}=$ bare sclera, $\mathrm{PC}=$ primary closure, $\mathrm{AMT}=$ amniotic membrane transplantation, $\mathrm{CAG}=$ conjunctival autograft, $\mathrm{CLAG}=$ conjunctival limbal autograft, $\mathrm{MMC}=$ mitomycin $\mathrm{C}$.

annivariate Cox regression analysis.

30 to $82 \%$, with the exception of two reports, ${ }^{5}$ have forced it into oblivion. Our experience is similar with recurrences of $46(19.4 \%)$ for primary and one (33.3\%) for recurrent pterygia among those with unilateral pterygium. We have stopped doing bare sclera excision with the advent of newer, more acceptable techniques with lower recurrence rates.

\section{Primary closure}

With this procedure for primary pterygium, recurrences of $16.7 \%(n=5)$ were noted. There are only three recent studies describing results of this technique with widely varying recurrence rates ranging from 2 to $69 \% .{ }^{14-16}$ Two of these $\mathrm{e}^{15,16}$ used a small sample with extremely high recurrences of $45^{16}$ and $69 \% .{ }^{15}$ In the third retrospective study despite a large number of patients, ${ }^{14}$ the description of the surgical technique and the number lost to follow-up were inadequate. Hence, the efficacy of primary closure has not been substantiated in literature and needs further study.

\section{AMT}

Amniotic membrane anatomically consists of epithelium, basement membrane, and avascular stroma. Its unique properties have promoted its use in several ocular surface disorders. ${ }^{17}$ The basement membrane promotes 


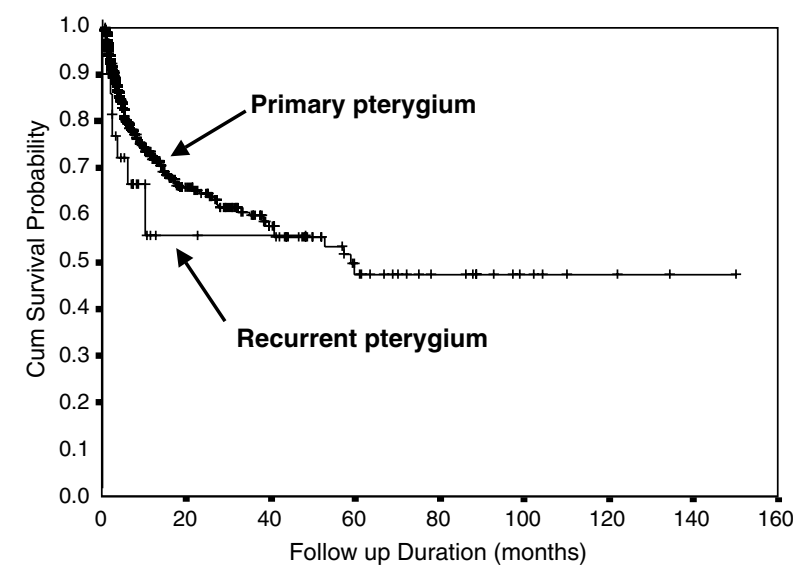

Figure 2 Kaplan-Meier survival analysis curves for primary and recurrent pterygia.

epithelial growth and differentiation and reinforces the adhesion of basal epithelial cells. The stromal matrix reduces scarring by suppressing TGF- $\beta$ signalling, proliferation, and myofibroblast differentiation in cultured human corneal and limbal fibroblasts ${ }^{18}$ and by suppressing normal conjunctival and pterygium body fibroblasts. ${ }^{19}$ Recurrence rates of 10.9 and $37.5 \%$ were reported with the use of amniotic membrane following excision of primary and recurrent pterygia respectively. ${ }^{16}$ These rates were significantly higher than those for CAG transplant. ${ }^{18}$ The same group subsequently described a modification of the surgical technique and reported recurrences of 3 and $9.5 \%$ for primary and recurrent pterygia respectively. ${ }^{20}$ The high recurrence rate of $26.7 \%$ noted in our study could be attributed to inadequate excision of the subconjunctival fibrous tissue. There is a lack of descriptive literature on this technique and prospective randomised controlled trials are needed. AMT will be useful in cases with extensive conjunctival defects or in those patients who may require glaucoma filtering procedures in the future.

\section{CAG transplantation}

The relatively lower recurrences with this technique could be due to transplantation of normal conjunctiva that forms a barrier to the proliferation and advancement of residual abnormal tissue (both conjunctival and episcleral tissues) towards the limbus and the noninclusion of episcleral tissue in the graft. ${ }^{15}$ In addition, scleral dessication and subsequent melting is prevented, ${ }^{20}$ and there is restoration of normal anatomic appearance. ${ }^{16}$ Our results with CAG reflect those of other groups. ${ }^{5}$ Recurrences of $12.2 \%(n=42)$ were noted in those with primary pterygium and $31.3 \%(n=5)$ in those with recurrent pterygium. Results of prospective randomised clinical trials performed in geographical areas with a higher prevalence of pterygium have shown higher recurrences of $21 \%$ and $39 \%{ }^{11}$ with CAG:

however, these values are still lower than those following bare sclera excision. The recurrences following CAG reported in the English language literature range from 0 to $40 \% .^{5}$ The variable results among several groups could be due to

1. different study populations, some within the tropics with higher exposure to UV

2. variations in surgical technique, that is, inadequate excision of episcleral tissue, graft retraction due to undersizing or inclusion of Tenon's tissue

3. diverse definitions of recurrence

4. small sample size

5. pterygium morphology.

Compared to bare sclera excision, the risk of recurrence following CAG was significantly lower (hazards ratio $0.67 ; 95 \%$ CI 0.43-1.05). Despite the retrospective nature of this study, this is the largest series of patients in whom CAG has been done and it appears to be a safe and effective procedure for primary

Table 6 CLAG outcome

\begin{tabular}{|c|c|c|c|c|c|c|c|c|}
\hline Year & $\begin{array}{l}\text { No. of eyes } \\
\text { (Prim;rec) }\end{array}$ & $\begin{array}{c}\operatorname{Rec} \% \\
\text { (Prim;rec) (eyes) }\end{array}$ & $\begin{array}{c}\text { Ave FU } \\
\text { (months) (range) }\end{array}$ & Surgery & Nature of study & $\begin{array}{c}\text { Control } \\
\text { (Prim;rec) }\end{array}$ & Surgery & Rec\% (eyes) \\
\hline $1994^{21}$ & $31(0 ; 31)$ & $13.3(4)$ & $10(3-18)$ & CLAG & Prospective & $18(0 ; 18)$ & Czermak & 50 \\
\hline $1996^{22}$ & $27(16 ; 11)$ & $6.25 ; 9.1(1 ; 1)$ & $10.87(1-34)$ & CLAG & $\begin{array}{l}\text { Prospective } \\
\text { noncomp }\end{array}$ & - & - & - \\
\hline $1998^{23}$ & $4(0 ; 4)$ & $25(1)$ & NA & $\mathrm{CLAG}+\mathrm{AMG}$ & $\begin{array}{l}\text { Prospective } \\
\text { noncomp }\end{array}$ & - & - & - \\
\hline $1998^{6}$ & $53(36 ; 17)$ & $3.8 ; 0(2 ; 0)$ & $18.9 \pm 2.1(1.5-43)$ & CLAG & Retro & - & - & - \\
\hline $2000^{24}$ & $7(0 ; 7)$ & 0 & $-(14-24)$ & CLAG & $\begin{array}{l}\text { Prospective } \\
\text { noncomp }\end{array}$ & - & - & - \\
\hline $2003^{25}$ & $34(0 ; 34)$ & 0 & - min. 18 months & $\mathrm{CLAG}+\mathrm{MMC}$ & Mixed $^{\mathrm{a}}$ & - & - & - \\
\hline $2003^{26}$ & $15(0 ; 15)$ & $20(3)$ & 16.75 & $\mathrm{CLAG}+\mathrm{AMG}$ & - & 12 & $\mathrm{CAG}+\mathrm{AMG}$ & $8.3(1)$ \\
\hline
\end{tabular}

No. $=$ number; $\quad$ Rec $=$ recurrence; $\quad$ Ave $\quad F U=$ average $\quad$ follow-up; Prim;rec $=$ primary;recurrent; $\quad C L A G=$ conjunctival limbal autograft; noncomp $=$ noncomparative; $\mathrm{AMG}=$ amniotic membrane graft; retro = retrospective; $\min =$ minimum; $\mathrm{MMC}=$ mitomycin $\mathrm{C}$.

${ }^{a}$ retrospective $(n=18)+$ Prospective $(n=16)$. 
pterygium. Most studies have not described their results of CAG for primary and recurrent pterygia separately. ${ }^{5}$

A report by Riordan-Eva et $a l^{15}$ in a retrospective study described recurrences of $6 \%$ in 17 of 47 eyes with recurrent pterygium. Recurrence rates of 0 and $9.1 \%$ have been described in prospective studies comprising of 17 and 44 eyes with recurrent pterygia each. ${ }^{10,16}$ We noted a higher recurrence rate of $31.3 \%$ (five of 11 eyes) with a small series of patients with recurrent pterygium. Larger prospective trials are needed to determine the efficacy of this technique for recurrent pterygia.

\section{CLAG}

Localised stem cell deficiency has been hypothesised to be a cause of pterygium. ${ }^{2}$ Based on this concept, a CLAG including limbal stem cells from a healthy site of the affected eye has been shown to be effective following pterygium excision with recurrences ranging from 0 to $25 \%$. The results with this technique have been described in Table $7 .^{21-26}$ A combination of AMT and CLAG has also been tried for recurrent pterygia. ${ }^{26}$ Excision of recurrent pterygia results in excessive fibrovascular regrowth. Multiple surgeries at the limbus result in destruction of limbal barrier function. Thus, a combination of CLAG for restoration of limbal barrier function, and AMT for suppressing the fibrous growth, have demonstrated good results (Table 7). We noted recurrence in nine (17.3\%) of 52 eyes with primary pterygia with this combined procedure. The recurrences were higher compared to the published literature. This may be attributed to inadequate excision of the subconjunctival tissue or due to an inadvertent selection bias in this retrospective analysis resulting in this procedure being performed for progressive, vascular pterygia in younger patients; however, this was assessed and there was no difference noted. When compared to CAG, there was no statistically significant difference in the recurrence rate. Of five eyes with recurrent pterygia, recurrences were seen in two (40\%). Conclusive evidence cannot be drawn regarding the use of this procedure for recurrent pterygia considering the small number of patients operated upon.

Table 7 Complications following pterygium surgery

\begin{tabular}{lrc}
\hline Complications & No. & $\%$ \\
\hline Scleral melt & 2 & 0.2 \\
Graft oedema & 13 & 1.3 \\
Microbial keratitis & 3 & 0.3 \\
Conjunctival granuloma & 8 & 0.8 \\
Tenon cyst & 2 & 0.2 \\
Total & 28 & 2.8 \\
\hline
\end{tabular}

No. $=$ number.

\section{Adjuvant therapy}

A total of $32(3.9 \%)$ patients with unilateral primary pterygia undergoing surgery received adjuvant intraoperative MMC therapy in doses varying from 0.2 to $0.4 \mathrm{mg} / \mathrm{ml}$ for varying durations from 1 to $4 \mathrm{~min}$.

Recurrences were noted among those who underwent bare sclera excision (Table 3). This high rate of recurrence compared to what has been described in literature, ${ }^{5}$ may be due to lack of uniformity in the surgical procedure and the relatively small sample size confounding the results. The major drawback of antimetabolites is the potential risk of scleral necrosis and perforation. Hence, the concomitant use of adjuvants has been recommended with caution for aggressive recurrent pterygium until adequate follow-up information has been obtained from those receiving MMC for primary pterygium. $^{5}$

We agree that this study, although comprising the largest series of cases describing outcome of various surgical techniques for pterygium, has all the limitations of a retrospective study. Prospective randomised case control studies comparing AMT, CAG and CLAG for primary pterygia and CAG and CLAG with and without the use of MMC for recurrent pterygia are needed.

\section{Conclusion}

CAG with or without AMG appears to be the safest and most effective modality for primary and recurrent pterygia. Males, patients below the age of 40 years, and those with vascular pterygia face greater risk of recurrence. Bare sclera excision and primary closure have high recurrence rates.

\section{References}

1 Hirst L. Distribution, risk factors, and epidemiology. In: Taylor HR (ed). Pterygium, Vol 2, Kugler Publications: The Hague, Netherlands, 2000, pp 15-28.

2 Dushku N, Reid TW. Immunohistochemical evidence that human pterygia originate from an invasion of vimentinexpressing altered limbal epithelial basal cells. Curr Eye Res 1994; 13: 473-481.

3 Li DQ, Lee SB, Gunja-Smith Z, Liu Y, Solomon A, Meller D et al. Overexpression of collagenase(MMP-1) and stromelysin (MMP-3) by pterygium head fibroblasts. Arch Ophthalmol 2001; 119: 71-80.

4 Oldenburg JB, Garbus J, McDonnell JM, McDonnell PJ. Conjunctival pterygia. Cornea 2000; 9(3): 200-204.

5 Hirst LW. The treatment of pterygium. Surv Ophthalmol 2003; 45: 145-180.

6 Rao SK, Lekha T, Mukesh BN, Sitalakshmi G, Padmanabhan P. Conjunctival-limbal autografts for primary and recurrent pterygia: technique and results. Indian J Ophthalmol 1998; 46: 203-209. 
7 Kim JC, Tseng SCG. Transplantation of preserved human amniotic membrane for surface reconstruction in severely damaged rabbit corneas. Cornea 1995; 14: 473-484.

8 Doughman DJ. In discussion: Kenyon KR, Wagoner MD, Hettinger ME. Conjunctival autograft transpantation for advanced and recurrent pterygium. Ophthalmology 1985; 92: 1470

9 Lewallen S. A randomised trial of conjunctival autografting for pterygium in the tropics. Ophthalmology 1989; 96 1612-1614

10 Tan DTH, Chee SP, Dear KBG, Lim ASM. Effect of pterygium morphology on pterygium recurrence in a controlled trial comparing conjunctival autografting with bare sclera. Arch 1997; 115: 1235-1240.

11 Chen PP, Ariyasu RG, Kaza V, LaBree LD, McDonnell PJ. A randomised trial comparing mitomycin $\mathrm{C}$ and conjunctival autograft after excision of primary pterygium. Am J Ophthalmol 1995; 120: 151-160.

12 Mannis CA, Kloess PM, Diaz D, Yee RW. Intraoperative mitomycin in primary pterygium excision. Ophthalmology 1997; 104: 844-848.

13 Wong WW. A hypothesis on the pathogenesis of pterygiums. Ann Ophthalmol 1978; 10: 303-308.

14 Anduze AL. Merest sclera technique for primary pterygium surgery. Ophthalmic Surg 1989; 20: 892-894.

15 Riordan-Eva P, Kielhorn I, Ficker LA, Steel DMcG, Kirkness $\mathrm{CM}$. Conjunctival autografting in the surgical management of pterygium. Eye 1993; 7: 634-638.

16 Prabhasawat P, Barton K, Burkett G, Tseng SCG. Comparison of conjunctival autografts, amniotic membrane grafts, and primary closure for pterygium excision. Ophthalmology 1997; 104: 974-985.

17 Sippel KC, Ma JJ, Foster CS. Amniotic membrane surgery. Curr Opin Ophthalmol 2001; 12(4): 269-281.
18 Tseng SCG, Li DQ, Ma X. Suppression of transforming growth factor isoforms, TGF- $\beta$ receptor II, and myofibroblast differentiation in cultured human corneal and limbal fibroblasts by amniotic membrane matrix. J Cell Physiol 1999; 179: 325-335.

19 Lee SB, Li DQ, Tan DT, Meller DC, Tseng SC. Suppression of TGF- $\beta$ signaling in both conjunctival fibroblasts and pterygial body fibroblasts by amniotic membrane. Curr Eye Res 2000; 20: 325-334

20 Ti SE, Tseng SCG. Management of primary and recurrent pterygium using amniotic membrane transplantation. Curr Opin Ophthalmol 2002; 13: 204-212.

21 Güler M, Sobaci G, Ilker S, Öztürk F, Mutlu FM, Yildirim E. Limbal-conjunctival autograft transplantation in cases with recurrent pterygium. Acta Ophthalmol 1994; 72: 721-726.

22 Shimazaki J, Yang HY, Tsubota K. Limbal autograft transplantation for recurrent and advanced pterygia. Ophthalmic Surg Lasers 1996; 27: 917-923.

23 Shimazaki J, Shinozaki N, Tsubota K. Transplantation of amniotic membrane and limbal autograft for patients with recurrent pterygium associated with symblepharon. $\mathrm{Br} \mathrm{J}$ Ophthalmol 1998; 82: 235-240.

24 Gris O, Güell JL, del Campo Z. Limbal-conjunctival autograft transplantation for the treatment of recurrent pterygium. Ophthalmology 2000; 107: 270-273.

25 Nabawi KS, Ghonim MA, Ali MH. Evaluation of limbal conjunctival autograft and low-dose mitomycin $C$ in the treatment of recurrent pterygium. Ophthalmic Surg Lasers Imaging 2003; 34: 193-196.

26 Shimazaki J, Kosaka K, Shimmura S, Tsubota K. Amniotic membrane transplantation with conjunctival autograft for recurrent pterygium. Ophthalmology 2003, 110: $119-124$ 